\title{
PENGARUH PEMBERIAN 1,25 DIHYDROXYVITAMIN D (CALCITRIOL) TERHADAP KADAR FIBROBLAST GROWTH FACTOR-23 DAN ALBUMINURIA PADA PASIEN PENYAKIT GINJAL KRONIK STADIUM V YANG MENJALANI HEMODIALISIS
}

\author{
THE EFFECT OF 1,25 DIHYDROXYVITAMIN D (CALCITRIOL) ON GROWTH \\ FACTOR CONTENT FIBROBLAST-23 AND ALBUMINURIA IN CHRONIC KIDNEY \\ DISEASE PATIENTS STADIUM V THOSE UNDERGOING HEMODIALYSIS
}

\author{
Intan Herlina, Bambang Purwanto, Sugiarto \\ Sub Bagian Ginjal dan Hipertensi, Bagian Ilmu Penyakit Dalam \\ FK UNS / RSUD Dr. Moewardi Surakarta \\ Korespondensi: Intan Herlina: dr.intansppd@gmail.com
}

\begin{abstract}
ABSTRAK
Penyebab utama morbiditas dan mortalitas pada pasien Penyakit Ginjal Kronik adalah insiden kardiovaskuler yang didasari oleh proses aterosklerosis yang menyebabkan meningkatnya morbiditas dan mortalitas. Ginjal merupakan tempat utama sintesa 1,25 Dihydroxyvitamin D (Calcitriol), sehingga dengan adanya kerusakan ginjal menyebabkan defisiensi 1,25 Dihydroxyvitamin D (Calcitriol). Pada pasien Penyakit Ginjal Kronik terjadi peningkatan Fibroblast Growth Factor-23 dan Albuminuria akibat dari aktifitas Renin Angiotensin Aldosteron Sistem. Aktifitas RAAS mempengaruhi 1,25 Dihydroxy vitamin D (Calcitriol), Fibroblast Growth Factor-23 melalui Angiotensin 2 dengan cara menghambat reseptor Angiotensin I (AT1) melalui Nicotinmide Adenine Dinucleotide Phosphate Oxidase (NADPH Oksidase) dan Stress Oxidativ. Beberapa penelitian menyimpulkan pemberian 1,25 Dihydroxyvitamin D (Calcitriol) mempunyai efek renoprotektif, anti inflamasi dan antiproteinuric dengan cara menghambat reseptor Angoitensin I (AT1) sehingga mengakibatkan menurunnya albuminuria. Tujuan Penelitian ini adalah untuk membuktikan pemberian 1,25 Dihydroxyvitamin $D$ (Calcitriol) dapat menurunkan kadar Fibroblas Growth Factor-23 dan albuminuria pada pasien Penyakit Ginjal Kronik stadium V yang menjalani hemodialisis. Penelitian ini merupakan penelitian eksperimen dengan randomisasi, subyek penelitian 30 orang, dibagi dalam dua kelompok sampel, kelompok plasebo 15 orang dan kelompok perlakuan 15 orang. Dalam perjalanan, kelompok placebo drop out 4 pasien karena keluarga pasien tidak menyetujui untuk melanjutkan penelitian dan satu lagi mengalami perburukan, sehingga jumlah sampel menjadi 26 orang, terbagi menjadi kelompok placebo sebanyak 11 orang yang diberi placebo dan kelompok perlakuan 15 orang diberi calcitriol 1x0,5 $\mu \mathrm{g}$ peroral selama 4 minggu. Karakteristik penelitian yang berupa variabel kualitatif, uji homogenitas dilakukan menggunakan uji Chi Square. Uji beda dua Rerata menggunakan uji t pada $p<0.005$. Pada kelompok plasebo $(n=11)$; Kadar Fibroblast Growth Factor-23 sebelum dan sesudah

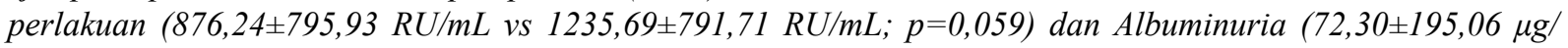

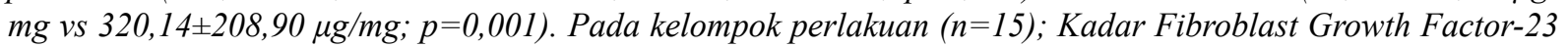
sebelum dan sesudah perlakuan $(1210,96 \pm 845,97 \mathrm{RU} / \mathrm{mL}$ vs $612,33 \pm 487,32 \mathrm{RU} / \mathrm{mL}$; $p=0$,002) dan Albuminuria $(206,63 \pm 327,25 \mu \mathrm{g} / \mathrm{mg}$ vs 192,89 $\pm 316,00 \mu \mathrm{g} / \mathrm{mg} ; \mathrm{p}=0,001)$. Terdapat perbedaan yang bermakna pada selisih ratarata kadar Fibroblast Growth Factor-23 (Delta-FGF-23) sebelum dan sesudah perlakuan pada kelompok placebo vs kelompok perlakuan $(-359,45 \pm 560,23 \mathrm{RU} / \mathrm{mL}$ vs 598,63 $\pm 608,27 \mathrm{RU} / \mathrm{mL} ; \mathrm{p}=0,001)$ dan selisih rata-rata Albuminuria (Delta-albuminuria) sebelum dan sesudah perlakuan pada kelompok placebo vs kelompok perlakuan $(-247,84 \pm 189,48 \mu \mathrm{g} / \mathrm{mg}$ vs 13,73 $\pm 23,15 \mu \mathrm{g} / \mathrm{mg} ; \mathrm{p}=0,001$. Pemberian suplementasi 1,25 Dihydroxyvitamin D (calcitriol) menurunkan kadar FGF-23 albuminuria secara bermakna pada pasien penyakit ginjal kronik stadium $V$ yang menjalani hemodialisis
\end{abstract}

Kata Kunci: Penyakit Ginjal Kronis Stadium V, 1,25 Dihydroxyvitamin D (Calcitriol), Fibroblast Growth Factor-23, Albuminuria 


\section{ABSTRACT}

The main cause of morbidity and mortality in patients with Chronic Kidney Disease is based on the incidence of cardiovascular atherosclerotic processes that lead to increased morbidity and mortality. Kidney is the major site of synthesis of 1,25 dihydroxyvitamin D (Calcitriol), so that the presence of kidney damage causes a deficiency of 1,25 dihydroxyvitamin D (Calcitriol). In patients with Chronic Kidney Disease increased Fibroblast Growth Factor-23 and albuminuria as a result of the activity of the Renin Angiotensin Aldosterone System. RAAS activity affects 1,25 dihydroxy vitamin D (Calcitriol), Fibroblast Growth Factor-23 through angiotensin 2 receptor by inhibiting angiotensin I (AT1) through Nicotinmide Oxidase adenine dinucleotide phosphate (NADPH oxidase) and Stress Oxidativ. Some studies suggest that 1,25 dihydroxyvitamin D (Calcitriol) have renoprotective effects, anti-inflammatory and antiproteinuric by inhibiting Angoitensin I receptor (AT1) thus resulting in reduced albuminuria. The Objective of this research is to prove the effect of 1,25 dihydroxyvitamin D (Calcitriol) that can reduce levels of fibroblast growth factor-23 and albuminuria in patients with Chronic Kidney Disease $V$ stadium undergoing hemodialysis. This study is a randomized experiment, research subjects 30 people, divided into two sample groups, the placebo group and the treatment group 15 to 15 people. The placebo group dropped out 4 patients because the patient's family does not agree to continue the research and another worsening, so the sample size to 26 people, divided into as many as 11 people in the placebo group were given a placebo and treatment groups of 15 people given the calcitriol 1x0,5 g orally for 4 weeks. Characteristics of research in the form of qualitative variables, homogeneity test was performed using Chi Square test. Two different test mean using parametric tests ( $t$ test)on $P<0.005$. In the placebo group $(n=11)$; Levels of Fibroblast Growth Factor-23 before and after treatment $(876.24 \pm 795.93 \mathrm{RU} / \mathrm{mL} v \mathrm{~s} 1235.69 \pm 791.71 \mathrm{RU} / \mathrm{mL} ; \mathrm{p}=0.059)$ and albuminuria $(195.06 \pm$ $72.30 \mathrm{pg} / \mathrm{mg}$ vs $320.14 \pm 208.90 \mathrm{pg} / \mathrm{mg} ; \mathrm{p}=0.001)$. In the treatment group $(n=15) ;$ Levels of Fibroblast Growth Factor-23 before and after treatment $(1210.96 \pm 845.97 \mathrm{RU} / \mathrm{mL}$ vs $612.33 \pm 487.32 \mathrm{RU} / \mathrm{mL} ; \mathrm{p}=0.002)$ and albuminuria (206.63 $\pm 327.25 \mathrm{pg} / \mathrm{mg} v \mathrm{vs} 192.89 \pm 316.00 \mathrm{pg} / \mathrm{mg} ; \mathrm{p}=0.001)$. There were significant differences in the average gap levels Fibroblast Growth Factor-23 (Delta-FGF-23) before and after treatment in treatment group vs. the placebo group $(-359.45 \pm 560.23 \mathrm{RU} / \mathrm{mL} v \mathrm{~s} 608 \pm 598.63,27 \mathrm{RU} / \mathrm{mL} ; \mathrm{p}=0.001)$ and the average gap albuminuria (Delta-albuminuria) before and after treatment in treatment group vs. the placebo group (-247.84 $\pm 189.48 \mathrm{pg} / \mathrm{mg}$ vs $13.73 \pm 23,15 \mu \mathrm{g} / \mathrm{mg} ; \mathrm{p}=0.001)$ Supplementation 1,25 dihydroxyvitamin $D$ (calcitriol) can reduced levels of FGF-23 significantly albuminuria in patients with stage V chronic kidney disease who undergo hemodialysis.

Keywords: Chronic Kidney Disease Stage V, 1,25 dihydroxyvitamin D (Calcitriol), Fibroblast Growth Factor-23 Albuminuria

\section{PENDAHULUAN}

Di Indonesia penyakit ginjal kronik (PGK) merupakan penyakit yang banyak dijumpai dan mencapai $29,1 \%$ dari populasi dengan berbagai faktor resiko (hipertensi, diabetes, proteinuria) (Suhardjono, 2009).

Prevalensi pasien dengan penyakit ginjal kronik semakin hari semakin meningkat, seiring dengan meningkatnya populasi lanjut usia dan meningkatnya jumlah pasien dengan diabetes dan hipertensi (Thomas et al, 2008). Pasien dengan penyakit ginjal kronik mempunyai resiko lebih besar untuk meninggal karena penyakit kardiovaskuler dibandingkan karena gagal ginjal. Pasien dengan penyakit ginjal kronik yang menjalani hemodialisa mempunyai resiko 10-30 kali lebih besar terjadi kematian karena penyakit kardiovaskuler, mempunyai resiko tinggi untuk menderita penyakit jantung, arterial vascular disease dan kardiomiopati (Sarnak et al, 2003).

Terdapat peningkatan morbiditas dan mortalitas pada pasien penyakit ginjal kronik terutama karena penyakit jantung vaskuler (PJV). Peningkatan terutama ditemukan pada pasien penyakit ginjal tahap akhir (PGTA) yang menjalani terapi pengganti ginjal (TPG). Angka mortalitas penyakit ginjal tahap akhir yang diterapi dengan hemodialisis tiga kali seminggu diperkirakan antara 14-26\% di Eropa dan 24\% di Amerika Serikat dan lebih dari 50\% kematian disebabkan oleh komplikasi jantung vaskuler, oleh karena itu mortalitas jantung vaskuler 10-20 kali lebih tinggi daripada populasi umum (Rayner, 2004).

Peningkatan inflamasi dan stres oksidatif merupakan faktor resiko non tradisional yang penting untuk penyakit jantung vaskuler yang teridentifikasi pada pasien penyakit ginjal kronik (Kendrick dan Chonchol, 2008). Dalam hal ini inflamasi kronis dan stres oksidatif lebih ditekankan dan mekanisme sinergis keduanya mempresentasikan kontributor penting perkembangan dan progresi percepatan proses 
aterosklerosis yang dihubungkan dengan penyakit jantung vaskuler dan penyakit ginjal kronik (Cachofeiro et al, 2008). Penyakit kardiovaskuler merupakan komplikasi yang sering terjadi pada pasien penyakit ginjal kronik dibandingkan populasi umum yang dapat menyebabkan meningkatkan morbiditas dan mortalitas pasien penyakit ginjal kronik (Collins, 2003; Sarnak et al 2003).

Beberapa kelainan patologik dan manifestasi klinik penyakit kardiovaskuler pada penyakit ginjal kronik terdapat kelainan pada arteri (aterosklerosis, arteriosklerosis). Aterosklerosis adalah radang pada pembuluh darah disebabkan oleh penumpukan plak ateromatous pada tunika intima, sedangkan arteriosklerosis adalah suatu remodeling dari arteri besar disertai dengan kalsifikasi tunika media dan berkurangnya elastisitas arteri. Presentasi klinis terjadi pada populasi umum antara lain penyakit jantung iskemik, penyakit serebrovascular, penyakit vaskuler perifer atau gagal jantung (Suhardjono, 2009).

Beberapa faktor resiko kardiovaskular dan disfungsi endotel dapat merangsang Nicotinamide Adenine Dinucleotide Phosphate Oxidase (NADPH Oksidase) pada mitokondria sehingga enzim tersebut akan mengekskresikan stres oksidatif. Stres oksidatif menyebabkan terjadinya disfungsi endotel. Disfungsi endotel akan meningkatkan progresifitas aterosklerosis (Gibbons, 1997).

Pasien penyakit ginjal kronik berada pada suatu kondisi dengan status inflamasi kronik yang dihubungkan dengan kalsifikasi vaskuler. Pada penelitian observasional menunjukkan adanya hiperphospatemia, tingginya kadar hormon paratiroid dan meningkatnya kalsifikasi vaskuler merupakan faktor resiko penyakit kardiovaskuler pada penyakit ginjal kronik. Pada pasien penyakit ginjal kronikdengan hiperparatiroid sekunder terjadi peningkatan kadar sitokin pro inflamasi sehingga regulasi dari inflamasi vaskuler sistemik dan proses kalsifikasi merupakan masalah penting pada pasien penyakit ginjal kronik yang menjalani hemodialisis (Tentori et al, 2008).

Hormon Paratiroid (PTH) dan vitamin D berperan dalam homeostasis mineral dan tulang. Fungsi utama dari PTH-vitamin D adalah untuk mempertahankan kadar kalsium serum dengan merangsang produksi 1,25-dihydroxyvitamin $D$ atau 1,25(OH)2 vitamin $D$ atau Calcitriol dan penurunan ekskresi kalsium urin oleh ginjal. Paratiroid Hormon meningkatkan kalsium dari tulang. Sekresi Paratiroid Hormon diatur oleh calsium sensing reseptor (CASR) terletak di kelenjar paratiroid, merespon kalsium serum terionisasi dengan meningkatkan sekresi Paratiroid Hormon, 84 asam amino peptida dengan Paratiroid HormonReseptor 1 (PTHR1) G protein-coupled reseptor padatubulus ginjal dan osteoblas/ osteosit dalam tulang. Paratiroid Hormon merangsang produksil,25(OH)2 vitamin Datau Calcitriol dalam tubulus proksimal dengan meningkatkan Cytochrome p450 27B1 (CYP27B1) dan meningkatkan reabsorpsi kalsium di tubulus distal melalui regulasi Transient Receptor Potential Cation Channel Subfamily V member 5(TRPV5) (De Groot, 2009). Paratiroid Hormon dalam tulang, meningkatkan kalsium dan fosfat melalui stimulasi Receptor Activator of Nuclear Factor Kappa-B Ligand (RANKL) oleh osteoblas yang pada gilirannya merangsang resorpsi tulang oleh osteoklas. Meningkatnya produksi 1,25(OH)2 vitamin Datau Calcitriol oleh ginjal dan usus kecil untuk meningkatkan penyerapan kalsium dan fosfat. Meningkatnya fosfat dari tulang dan masuknya dari jalur gastrointestinal adalah seimbang dengan efek Paratiroid Hormon menurunkan reabsorbsi fosfat oleh tubulus ginjal untuk menjaga keseimbangan fosfat netral.

Penurunan fungsi ginjal pada penyakit ginjal kronik disertai dengan penurunan produksi 1,25-dihydroxyvitamin $D$ atau $1,25(\mathrm{OH}) 2$ vitamin $D$ atau Calcitriol, dimulai pada penyakit ginjal kronik stadium 2 yang secara progresif bertambah rendah dengan bertambahnya stadium penyakit. Rendahnya kadar 1,25-dihydroxy vitamin $D$ (Calcitriol) tersebut menyebabkan beberapa efek samping pada pasien penyakit ginjal kronik meliputi gangguan pada homeostasis mineral tulang dan hormon paratiroid, kalsifikasi ekstraskeletal dan terganggunya fungsi biologi multiorgan (Moscovici dan Sprague, 2007).

\section{1,25-dihydroxyvitamin $D$ (Calcitriol)} dikenal merupakan terapi lini pertama yang dapat menekan kadar hormon paratiroid pada pasien penyakit ginjal kronik dengan hiperpartiroid sekunder. Selain menekan kadar hormon paratiroid, vitamin D juga dapat memodulasi respon imun dan diferensiasi sel. Karena efek tersebut diharapkan dapat mengontrol status inflamasi pada pasien 
penyakit ginjal kronik dan pemberian vitamin D dapat menekan mortalitas pada pasien penyakit ginjal kronik. 1,25-dihydroxyvitamin D (Calcitriol) juga mencegah nefrosklerosis dan memperlambat progresivitas penyakit ginjal kronik melalui efek anti inflamasi dan anti proliferatifnya (Teng et al, 2003).

Peran 1,25-dihydroxyvitamin D (Calcitriol) sebagai anti inflamasi melalui penekanan pada jalur Nuclear Factor $k B$ (NF-KB), dimana jalur Nuclear Factor $k B$ ini sangat berperan penting dalam progresivitas penyakit ginjal, karena jalur tersebut akan memicu inflamasi dan fibrogenesis melalui pelepasan sitokin pro inflamasi (Lang, 2014). Peran vitamin D aktif dalam mengatasi fibrosis ginjal dan disfungsi ginjal pada beberapa jalur patogen berkorelasi antara menurunnya vitamin $\mathrm{D}$ aktif pada ginjal dan rendahnya kadar serum 1,25(OH)2D3 atau Calcitriol sering dikaitkan dengan penurunan fungsi ginjal (Llach dan Yudd, 1998).

Fibroblast Growth Factor-23(FGF-23) disekresi oleh tulang dan ginjal untuk mengatur metabolisme vitamin $\mathrm{D}$ dan fosfat di ginjal (Yamashita et al., 2000). Fibroblast Growth Factor-23 berinteraksi dengan reseptor FGF (FGFRs) sebagai kofaktor klotho (Goetz, 2007). Klotho memfasilitasi pengikatan Fibroblast Growth Factor-23 ke Fibroblast Growth Factor Reseptor 1c (FGFR1c, FGFR3c dan FGFR4). (Kurosu, 2006; Urakawa, 2006). Fibroblast Growth Factor Reseptor (FGFRs) mengandung sinyal transducing ekstraseluler ligan binding domain dan intraseluler tirosine kinase domain. Ekspresi klotho menentukan spesifisitas fungsi jaringan Fibroblast Growth Factor-23 (Kurosu, 2006; Torres, 2007).

Fibroblast growth factor-23 (FGF-23) adalah tumor yang melepaskan Fibroblast growth factor-23, menghasilkan hypophos phatemia dan penurunan kadar serum 1,25 $(\mathrm{OH}) 2$ vitamin D (White, 2000; Shimada, 2004). Sebaliknya tikus atau manusia dengan penurunan Fibroblast growth factor-23atau dengan penghapusan Klotho sebagai koreseptor penting untuk Fibroblast growth factor-23, hyperphosphatemia dan peningkatan serum 1,25 $(\mathrm{OH}) 2$ vitamin D3 (Kurosu, 2006; Araya, 2005). Di samping itu, klotho mRNA dan protein yang ditampilkan, Fibroblast growth factor-23 konsentrasinya jauh lebih besar di ginjal daripada di setiap organ. Ditentukan oleh reseptor
Klotho Fibroblast Growth Factor Reseptor 1c (FGFR1c) heterodimer di tubulus distal ginjal (Farrow, 2009).

Klotho tidak hanya terdapat di ginjal tetapi juga pada organ lain. Ekspresi klotho terdapat di ginjal, sinoatrial node hati, pleksus koroid dan paratiroid. Fibroblast growth factor-23 mengikat KlothoFibroblast Growth Factor Reseptorlc(FGFR1c) heterodimer dan mengaktif kan jalur transduksi Mitogen Activated Protein Kinase (MAPK), menyebabkan penurunan Sodium Phosphate Cotransporter $2 a(\mathrm{NaPi} 2 \mathrm{a})$ ginjal dan fosfaturia serta penghambatan $25(\mathrm{OH})$ vitamin D1 ase (OH), Cytochrome p450 27B1 (CYP27B1), penurunan kadar serum $1,25(\mathrm{OH}) 2$ vitamin $\mathrm{D}$. Pleksus koroid klotho memiliki peran dalam transfer kalsium yang dimediasi oleh Natrium/ Kalium ATPase $\left(\mathrm{Na}^{+} / \mathrm{K}^{+}\right.$ATPase) (Kurosu, 2006; Urakawa, 2006).

Albuminuria sangat penting sebagai marker disfungsi endotel pada seluruh pembuluh darah baik pada ginjal, jantung koroner dan serebral. Bila terjadi kenaikan albuminuri (mulai dari mikroalbuminuri) akan terjadi meningkat nya resiko renokardioserebral vaskuler, sehingga perlu diantisipasi untuk mencegah peningkatan resiko tersebut. Keadaan mikroalbuminuria harus diperhatikan sebab merupakan tanda peningkatan resiko reno kardio serebro vaskuler dan kondisi tersebut masih reversibel, sehingga faktor pemberat (hipertensi, hiperlipidemi, diabetes mellitus) harus di kendalikan. Bila sudah terjadi makro albuminuri, proses disfungsi endotel menjadi iriversible, sehingga tidak bisa membuat normal target organ tetapi hanya berusaha mengurangi progresifitas kerusakan target organ (Purwanto`, 2012).

Kaitan antara mikroalbuminuria dengan komplikasi kardiovaskular sebetulnya belum jelas, akan tetapi mikroalbuminuria dapat terjadi karena disfungsi endotel atau merupakan konsekuensi penyakit vaskular secara umum. Disfungsi endotel dan inflamasi kronik dapat menerangkan kaitan antara mikroalbuminuria dengan kelainan kardiovaskular yang terjadi kemudian (Brantsma, 2006).

Studi lain, mikroalbuminuria sebagai prediktor dan prognosis infark miokardial. Studi ini menunjukkan bahwa pendekatan melalui pengukuran albumin dalam urin ini cukup efektif dalam mencegah penyakit jantung dan 
pada beberapa kelompok dengan resiko tinggi terjadinya albuminuria menjadi sangat bermanfaat (Gansevort, 2009; Newman dan Price, 2001).

Studi tentang albuminuria sebagai predictor hemorrhagic transformation pada acute ischemic stroke dengan kesimpulan bahwa rata-rata kadar albuminuria pada derajat klinis ringan lebih rendah daripada kadar albuminuria pada derajat klinis sedang dan terdapat hubungan bermakna antara derajat klinis penderita stroke iskemik dengan kadar albuminuria (Pedrinelli, 1994).

Fibroblast Growth Factor-23 (FGF23) merupakan anggota subfamili FGF19 dari FGFs endokrin yang juga mencakup Fibroblast Growth Factor (FGF) 15/19 dan Fibroblast Growth Factor 21/23. Fibroblast Growth Factor-23 terutama terdapat di osteosit dan osteoblas dalam tulang tapi juga terdapat pada kelenjar ludah, lambung dan jaringan lain termasuk otot rangka, otak, kelenjar susu dan hati. Gen Fibroblast Growth Factor-23 terletak pada kromosom 12 pada manusia dan kromosom 6 pada tikus oleh 3 exons, dipisahkan oleh 2 intron dan encode $32-\mathrm{kDa}$ glikoprotein yang mengandung 251 asam amino residu.

Fibroblast Growth Factor-23 ber tanggung jawab atas gejala klinis pasien yang menderita autosomal dominan hypophos phatemic riketsia. Mutasi ini mencegah proteolitik pembelahan proteinFibroblastGrowthFactor-23, meningkatkan aktivitas biologis dan mengakibatkan kerusakan ginjal. Fibroblast Growth Factor-23/ axis ginjal memiliki setidaknya dua fungsi fisiologis: 1) untuk memberikan sinyal phosphaturic yang berasal dari tulang untuk mengkoor dinasikan fluks fosfat pada tulang karena perubahan pergantian tulang dan mineralisasi dengan fosfat di ginjal

2) memberikan hormon counter regulatory untuk melindungi organisme dari paparan vitamin D yang berlebihan dengan penekanan Fibroblast Growth Factor-23 dimediasi produksi 1,25 (OH)2 vitamin $D$ dan peningkatan katabolisme oleh ginjal. Fibroblast Growth Factor-23 memiliki fungsi lain untuk mengatur fosfat, fungsi kelenjar paratiroid.

Derajat proteinuria diasosiasikan dengan penurunan ginjal progresif pada penyakit glomerular yang berkembang menuju Penyakit Ginjal Kronik. Proteinuria terjadi karena lintasan transglomerular abnormal akibat peningkatan permeabilitas dinding kapiler glomerulus dan gangguan reabsorbsi protein oleh sel epitel tubulus proksimal. Kerusakan dinding kapiler glomerulus berkorelasi dengan menurunnya sialoglycoprotein yang melapisi sel endotel, fusi dari foot processes podosit dan terangkatnya sel dari membran basal glomerulus (Glomerular Basment Membrane). Berkurang nya muatan negatif pada dinding kapiler menyebabkan albumin lolos dalam urin (Amicon \& Bazzi, 2003).

Suatu studi baru menunjukkan bahwa adanya protein yang terbuang dalam urin dapat mengidentifikasi meningkatnya resiko penyakit reno kardio serebro vaskuler. Dari hasil penelitan tersebut para peneliti menyimpulkan bahwa pada individu dengan kadar proteinuria tinggi terjadi peningkatan resiko penurunan fungsi ginjal, akhirnya pasien memerlukan dialisis atau transplantasi ginjal. Semakin tinggi kadar protein urin, semakin tinggi resiko pasien memerlukan dialisis atau transplantasi ginjal dan semakin cepat penurunan fungsi ginjal (Gansevort, 2009). Bila terjadi peningkatan stres oksidatif akan meningkatkan jumlah apoptosis pada podosit atau slit diafragma sehingga akan menyebabkan kerusakan sistem filtrasi dan menyebabkan kebocoran sistem filtrasi akhirnya akan menyebabkan peningkatan albuminuria.

Penelitian ini bertujuan untuk Membuktikan pemberian 1,25 Dihydroxyvitamin D (calcitriol) dapat menurunkan kadar Fibroblast Growth Factor-23 dan albuminuria pada pasien penyakit ginjal kronik stadium $\mathrm{V}$ yang menjalani hemodialisis.

\section{METODE PENELITIAN}

Jenis penelitian ini adalah uji klinis dengan randomized controlled trial, dilakukan di instalasi hemodialisa RSUD Dr. Moewardi Surakarta pada bulan februari s.d maret 2015. Melibatkan 30 pasien PGK stadium $\mathrm{V}$ dengan kriteria inklusi pasien sudah tegak diagnosis PGK stadium $\mathrm{V}$ yang dibuktikan dengan pemeriksaan USG ginjal, laboratorium darah dan pemeriksaan urin memenuhi kriteria K/ DOQI 2006, Usia 20-59 tahun, telah menjalani hemodialisis satu sampai dua kali seminggu selama lebih dari tiga bulan dan kurang dari 5 tahun, tensi sistolik lebih dari $100 \mathrm{mmHg}$, Hb lebih dari $6 \mathrm{mg} / \mathrm{dL}$, pasien dalam keadaan tidak mengkonsumsi suplemen Calcium (baik berupa tablet Calcium ataupun susu tinggi Calcium). Kriteria eksklusi Pasien PGK dengan 
nefropati diabetik stadium V,Pasien PGK yang sedang menjalani terapi dengan steroid, Pasien PGK yang sedang menjalani terapi vitamin D, Pasien PGK stadium V dengan keganasan, Pasien PGK stadium V dengan uropati obstruktif, Pasien dalam keadaan sepsis, Pasien dalam kondisi infeksi ( dibuktikan dengan suhu tidak lebih dari $37,5^{\circ} \mathrm{C}$ ), didapatkan aritmia jantung, tidak menderita hepatitis $\mathrm{B}$ dan $\mathrm{C}$ kronik.

Pasien dibagi menjadi dua kelompok menggunakan metode simple random sampling dengan Open Epi versi 2.3 menjadi kelompok kontrol sebanyak 15 pasien yang diberikan plasebo dan kelompok perlakuan sebanyak 15 pasien yang diberikan calcitriol $0,5 \mu \mathrm{g}$ / hari selama 4 minggu. Selama penelitian ber langsung, regimen terapi pasien tidak dirubah dan dikontrol tiap dua minggu untuk menilai ketaatan minum obat serta mencari efek samping yang mungkin timbul.

Prinsip pemeriksaan FGF-23 dengan menggunakan tehnik Sandwich ELISA Quantitative dengan menggunakan sampel serum/ plasma.
Teknik pemeriksaan dengan buffer, pipeting atau mencuci. Pengeenceran optimal menggunakan tabung polypropylene. Semua reagen disimpan pada suhu kamar.

Data disajikan dalam bentuk mean $\pm S D$ kemudian dianalisis menggunakan SPSS 17 for windows dengan nilai $\mathrm{p}<0,05$ dianggap signifikan secara statistik. Digunakan uji beda mean. Untuk mengetahui beda mean antara kelompok perlakuan dan kontrol sebelum dan sesudah perlakuan digunakan uji $t$ sampel independen. Untuk mengetahui beda mean antara sebelum dengan sesudah perlakuan dalam satu kelompok digunakan uji t sampel berpasangan.

\section{HASIL DAN PEMBAHASAN}

Karakteristik dasar subyek penelitian dan uji homogenitas dapat dilihat pada tabel 1. Berdasarkan data tersebut tampak bahwa karakteristik dasar subyek penelitian pada kelompok kontrol dan kelompok perlakuan adalah homogen

Tabel 1. Karakteristik subyek penelitian

\begin{tabular}{|l|c|c|c|c|c|c|}
\hline \multirow{2}{*}{ Variabel } & \multicolumn{2}{|c|}{ Placebo } & \multicolumn{2}{c|}{ Perlakuan } & \multicolumn{2}{c|}{ Uji Beda 2 Mean } \\
\cline { 2 - 7 } & $\begin{array}{c}\text { Rata- } \\
\text { rata }\end{array}$ & $\begin{array}{c}\text { Std } \\
\text { Deviasi }\end{array}$ & $\begin{array}{c}\text { Rata- } \\
\text { rata }\end{array}$ & $\begin{array}{c}\text { Std } \\
\text { Deviasi }\end{array}$ & $\begin{array}{c}\text { Nilai } \\
\text { Statistik }\end{array}$ & P value \\
\hline Lama HD & 1,44 & 1,06 & 2,17 & 1,98 & $\mathrm{Z}=-0,809$ & 0,443 \\
\hline Sistole & 148,18 & 17,22 & 159,33 & 22,82 & $\mathrm{t}=-1,359$ & 0,187 \\
\hline Diastole & 90,91 & 5,39 & 95,33 & 9,15 & $\mathrm{Z}=-1,251$ & 0,281 \\
\hline BB & 53,73 & 8,13 & 55,87 & 10,26 & $\mathrm{t}=-0,572$ & 0,573 \\
\hline HB & 9,15 & 1,10 & 9,66 & 0,88 & $\mathrm{t}=-1,299$ & 0,206 \\
\hline AL & 7,41 & 1,27 & 7,59 & 0,80 & $\mathrm{t}=-0,455$ & 0,653 \\
\hline Ureum & 125,91 & 47,82 & 134,13 & 58,01 & $\mathrm{t}=-0,384$ & 0,705 \\
\hline Cretinin & 10,67 & 1,90 & 11,07 & 4,66 & $\mathrm{t}=-0,265$ & 0,793 \\
\hline Kalsium & 1,02 & 0,08 & 0,99 & 0,08 & $\mathrm{Z}=-1,254$ & 0,217 \\
\hline Albumin & 3,78 & 0,23 & 3,75 & 0,24 & $\mathrm{t}=0,373$ & 0,713 \\
\hline Vitamin D Total & 17,69 & 7,82 & 14,47 & 3,88 & $\mathrm{t}=1,387$ & 0,178 \\
\hline GDS & 131,00 & 18,76 & 138,87 & 15,72 & $\mathrm{t}=-1,162$ & 0,257 \\
\hline
\end{tabular}

Keterangan : *) Signifikan pada derajat signifikansi 5 persen.

Hasil pengujian beda 2 mean kelompok placebo dan perlakuan untuk variabel kadar FGF-23 dan Albuminuria pada kondisi sebelum perlakuan pemberian 1,25 Dihydroxyvitamin D (Calcitriol) menunjukkan hasil pengujian yang tidak signifikan pada derajat signifikansi 5 persen $(p>0,05)$. Dengan demikian variable FGF23 dan Albuminuria untuk kelompok placebo dan perlakuan pada kondisi sebelum perlakuan pemberian 1,25 Dihydroxyvitamin D (Calcitriol) tidak berbeda secara meyakinkan atau berarti kedua rata-rata itu relative sama. 
Tabel 2. Perbandingan Variabel Fibroblast Growth Factor-23 dan Albuminuria pada Kelompok Plasebo dan Perlakuan di Kondisi Sebelum Perlakuan

\begin{tabular}{|l|c|c|c|c|c|c|}
\hline \multirow{2}{*}{ Variabel } & \multicolumn{2}{|c|}{ Placebo } & \multicolumn{2}{c|}{ Perlakuan } & \multicolumn{2}{c|}{ Uji Beda 2 Mean } \\
\cline { 2 - 7 } & Rata-rata & $\begin{array}{c}\text { Std } \\
\text { Deviasi }\end{array}$ & Rata-rata & $\begin{array}{c}\text { Std } \\
\text { Deviasi }\end{array}$ & $\begin{array}{c}\text { Nilai } \\
\text { Statistik }\end{array}$ & P value \\
\hline $\begin{array}{l}\text { Fibroblast Growth } \\
\text { Factor-23 }\end{array}$ & 876,24 & 795,93 & 1210,96 & 845,97 & $\mathrm{t}=-1,021$ & 0,317 \\
\hline Albuminuria & 72,30 & 195,06 & 206,63 & 327,25 & $\mathrm{Z}=-1,012$ & 0,330 \\
\hline
\end{tabular}

Keterangan: *) Signifikan pada derajat signifikansi 5 persen $(\mathrm{p}<0,05)$.

**) Signifikan pada derajat signifikansi 1 persen $(p<0,01)$.

Hasil pengujian beda 2 mean kelompok placebo dan perlakuan untuk variable Fibroblast Growth Factor-23 dan Albuminuria pada kondisi sesudah perlakuan pemberian 1,25 Dihydroxyvitamin D (Calcitriol) menunjukkan hasil pengujian yang signifikan untuk variable Fibroblast Growth Factor-23 dan Albuminuria dengan derajat signifikansi 5 persen $(p<0,05)$. Hal itu berarti setelah mendapat perlakuan pemberian 1,25 Dihydroxyvitamin D (Calcitriol) variable Fibroblast Growth Factor-23 dan Albuminuria pada kelompok perlakuan masing-masing memiliki rata-rata lebih rendah (mengalami penurunan) secara meyakinkan.

Tabel 3. Perbandingan Fibroblast Growth Factor- 23 dan Albuminuria Kelompok Placebo dan Perlakuan pada Kondisi Sesudah Perlakuan.

\begin{tabular}{|l|c|c|c|c|c|c|}
\hline \multirow{2}{*}{ Variabel } & \multicolumn{2}{|c|}{ Placebo } & \multicolumn{2}{c|}{ Perlakuan } & \multicolumn{2}{c|}{ Uji Beda 2 Mean } \\
\cline { 2 - 7 } & Rata-rata & $\begin{array}{c}\text { Std } \\
\text { Deviasi }\end{array}$ & Rata-rata & $\begin{array}{c}\text { Std } \\
\text { Deviasi }\end{array}$ & $\begin{array}{c}\text { Nilai } \\
\text { Statistik }\end{array}$ & P value \\
\hline $\begin{array}{l}\text { Fibroblast Growth } \\
\text { Factor-23 }\end{array}$ & 1235,69 & 791,71 & 612,33 & 487,32 & $\mathrm{t}=2,484$ & $0,020^{*}$ \\
\hline Albuminuria & 320,14 & 208,90 & 192,89 & 316,00 & $\mathrm{Z}=-2,103$ & $0,036^{*}$ \\
\hline
\end{tabular}

Keterangan : *) Signifikan pada derajat signifikansi 5 persen.

**) Signifikan pada derajat signifikansi 1 persen.

Hasil pengujian beda 2 mean variabel Fibroblast Growth Factor-23 sebelum dan sesudah perlakuan pada kelompok placebo menunjukkan bahwa rata-rata variable Fibroblast Growth Factor-23 tersebut berubah meningkat tidak signifikan pada derajat signifikansi 5 persen $(p>0,05)$. Sedangkan pengujian beda 2 mean variabel Albuminuria sebelum dan sesudah perlakuan pada kelompok placebo bahwa ratarata variabel Albuminuria itu berubah meningkat signifikan pada derajat signifikansi 5 persen $(p<0,05)$.

Tabel 4. Perbandingan Fibroblast Growth Factor-23 dan Albuminuria Sebelum dan Sesudah Perlakuan pada Kelompok Placebo

\begin{tabular}{|l|c|c|c|c|c|c|}
\hline \multirow{2}{*}{ Variabel } & \multicolumn{2}{|c|}{ Sebelum } & \multicolumn{2}{c|}{ Sesudah } & \multicolumn{2}{c|}{ Uji Beda 2 Mean } \\
\cline { 2 - 7 } & Rata-rata & $\begin{array}{c}\text { Std } \\
\text { Deviasi }\end{array}$ & Rata-rata & $\begin{array}{c}\text { Std } \\
\text { Deviasi }\end{array}$ & $\begin{array}{c}\text { Nilai } \\
\text { Statistik }\end{array}$ & P value \\
\hline $\begin{array}{l}\text { Fibroblast Growth } \\
\text { Factor-23 }\end{array}$ & 876,24 & 795,93 & 1235,69 & 791,71 & $\mathrm{t}=-2,128$ & 0,059 \\
\hline Albuminuria & 72,30 & 195,06 & 320,14 & 208,90 & $\mathrm{t}=-4,338$ & $0,001^{*}$ \\
\hline
\end{tabular}

Keterangan: * Signifikan pada Derajat Signifikansi 5 persen. 
Hasil pengujian beda 2 mean sampel berpasangan variabel Fibroblast Growth Factor-23 dengan menggunakan uji $\mathrm{t}$ untuk sampel berpasangan menunjukkan hasil pengujian yang signifikan pada derajat signifikansi sebesar 5 persen $(\mathrm{p}<0,05)$. Demikian pula hasil pengujian beda 2 mean berpasangan atas variabel Albuminuria sebelum dan sesudah perlakuan pada kelompok sampel perlakuan menunjukkan hasil pengujian yang signifikan pada derajat signifikansi sebesar 5 persen $(p<0,05)$ untuk kedua variabel tersebut. Hal itu dapat diartikan bahwa setelah mendapatkan perlakuan pemberian 1,25 Dihydroxyvitamin D (Calcitriol), variabel Fibroblast Growth Factor-23 dan Albuminuria mengalami perubahan secara meyakinkan. Variabel Fibroblast Growth Factor-23 setelah perlakuan mengalami perubahan yang menurun secara meyakinkan, demikian pula variabel Albuminuria setelah perlakuan juga mengalami perubahan yang menurun secara signifikan.

Tabel 5. Perbandingan Fibroblast Growth Factor-23 dan Albuminuria Sebelum dan Sesudah Perlakuan pada Kelompok

\begin{tabular}{|l|c|c|c|c|c|c|}
\hline \multirow{2}{*}{\multicolumn{1}{|c|}{ Variabel }} & \multicolumn{2}{|c|}{ Sebelum } & \multicolumn{2}{c|}{ Sesudah } & \multicolumn{2}{c|}{ Uji Beda 2 Mean } \\
\cline { 2 - 7 } & Rata-rata & $\begin{array}{c}\text { Std } \\
\text { Deviasi }\end{array}$ & Rata-rata & $\begin{array}{c}\text { Std } \\
\text { Deviasi }\end{array}$ & $\begin{array}{c}\text { Nilai } \\
\text { Statistik }\end{array}$ & P value \\
\hline $\begin{array}{l}\text { Fibroblast Growth } \\
\text { Factor-23 }\end{array}$ & 1210,96 & 845,97 & 612,33 & 487,32 & $\mathrm{t}=3,812$ & $0,002^{* *}$ \\
\hline Albuminuria & 206,63 & 327,25 & 192,89 & 316,00 & $\mathrm{t}=-3,408$ & $0,001^{* *}$ \\
\hline
\end{tabular}

Keterangan: * Signifikan pada Derajat Signifikansi 5 persen.

** Signifikan pada Derajat Signifikansi 1 persen.

Dari data di atas terlihat bahwa terdapat pengaruh pemberian1,25 Dihydroxyvitamin D (Calcitriol) terhadap kadar Fibroblast Growth
Factor-23 dan albuminuria pada pasien Penyakit Ginjal Kronik Stadium V yang menjalani hemodialysis.

Tabel 6. Perbandingan Delta Fibroblast Growth Factor-23 dan Delta Albuminuria pada Kelompok Placebo dan Kelompok Perlakuan.

\begin{tabular}{|c|c|c|c|c|c|c|}
\hline \multirow{2}{*}{ Variabel } & \multicolumn{2}{|c|}{ Placebo } & \multicolumn{2}{c|}{ Perlakuan } & \multicolumn{2}{c|}{ Uji Beda 2 Mean } \\
\cline { 2 - 7 } & Rata-rata & $\begin{array}{c}\text { Std } \\
\text { Deviasi }\end{array}$ & Rata-rata & $\begin{array}{c}\text { Std } \\
\text { Deviasi }\end{array}$ & $\begin{array}{c}\text { Nilai } \\
\text { Statistik }\end{array}$ & P value \\
\hline $\begin{array}{l}\text { Delta-Fibroblast } \\
\text { Growth Factor-23 }\end{array}$ & $-359,45$ & 560,23 & 598,63 & 608,27 & $\mathrm{t}=-5,332$ & $0,001^{* * *}$ \\
\hline Delta-albuminuria & $-247,84$ & 189,48 & 13,73 & 23,15 & $\mathrm{t}=-4,100$ & $0,001^{* * *}$ \\
\hline
\end{tabular}

Keterangan : "Signifikan palia Derajat Signifikansi 5 persen.

** Signifikan pada Derajat Signifikansi 1 persen.

Nampak bahwa perubahan Fibroblast Growth Factor-23 (delta-Fibroblast Growth Factor-23) dan perubahan Albuminuria (deltaalbuminuria) pada kelompok placebo masingmasing negatif yang berarti sebelum diberi 1,25 Dihydroxyvitamin D (Calcitriol) kedua variabel itu cenderung mengalami peningkatan, namun setelah diberikan perlakuan dengan pemberian 1,25 Dihydroxyvitamin D (Calcitriol) masing- masing variabel Fibroblast Growth Factor-23 dan Albuminuria meningkat hal itu nampak pada selisih kedua variabel pada kelompok perlakuan yang bernilai rata-rata positif.

Penyebab utama morbiditas dan mortalitas pada pasien Penyakit Ginjal Kronik adalah insiden kardiovaskuler yang didasari oleh proses aterosklerosis. Stres oksidatif dan reaksi inflamasi merupakan faktor yang bertanggung 
jawab dalam pembentukan dan perkembangan plak arteriosklerotik (Montesa et al, 2009). Peningkatan kadar substansi pro oksidan dan penurunan kadar antioksidan pada pasien dialisis memainkan peran penting terjadinya stres oksidatif dan menghasilkan kerusakan molekul yang ireversibel. Adanya hubungan antara stres oksidatif dan insiden kardiovaskuler pada pasien hemodialisis telah dibuktikan oleh banyak penelitian (Payson et al, 2004).

Fibroblast Growth Factor-23 sangat penting untuk mempertahankan homeostasis fosfat dan dikaitkan dengan regulasi metabolisme vitamin D (1,25 (OH) 2 D 3) (Liu et al, 2006). Fibroblast Growth Factor-23 berinteraksi dengan reseptor Fibroblast Growth Factor Reseptor (FGFRs) karena adanya kofaktor klotho (Goetz et al 2007; Kurosu et al, 2006; Urakawa et al, 2006). Gen klotho mengkode protein transmembran dengan ekstraseluler domain terdiri dari dua domain homolog yang urutan homolog dengan b-glukosidase. Klotho memfasilitasi pengikatan Fibroblast Growth Factor-23 untuk Fibroblast Growth Factor Reseptor FGFR1c, FGFR3c dan FGFR4 (Kurosu et al, 2006; Urakawa et al, 2006).

Fibroblast Growth Factor-23 mempunyai efek menghambat kalsifikasi melalui penurunan kalsium serum dan kadar fosfat. Shimada menunjukkan Fibroblast Growth Factor-23 dapat menekan ekspresi ginjal dari enzim 1a-hidroksilase dengan mengubah metabolit vitamin D ke dalam bentuk aktif (Shimada T et al, 2004). Fibroblast Growth Factor-23 dapat mengurangi kalsifikasi dengan menghambat aktivitas vitamin D. Inaba baru-baru ini melaporkan bahwa Fibroblast Growth Factor-23 merupakan faktor independen yang berhubungan dengan kalsifikasi pada arteri, tetapi tidak pada aorta pada pasien yang menjalani hemodialisis (Inaba et al, 2006).

Peran vitamin D sebagai anti inflamasi melalui penekanan pada jalur Nuclear Factor kB (NF-kB), dimana jalur Nuclear Factor kB ini sangat berperan penting dalam progresivitas penyakit ginjal, karena jalur tersebut akan memicu inflamasi dan fibrogenesis melalui pelepasan sitokin pro inflamasi (Lang, 2014). Peran vitamin D aktif dalam mengatasi fibrosis ginjal dan disfungsi ginjal pada beberapa jalur patogen berkorelasi antara menurunnya vitamin $\mathrm{D}$ aktif pada ginjal dan rendahnya kadar serum 1,25(OH)2D3 atau
Calcitriol sering dikaitkan dengan penurunan fungsi ginjal (Llach dan Yudd, 1998).

Vitamin D juga mencegah nefrosklerosis dan memperlambat progresivitas PGK melalui efek anti inflamasi dan anti proliferatimya. Pada pasien PGK stadium 3-5, terapi dengan calcitriol dihubungkan dengan tren ke depan dapat memperlambat kebutuhan inisiasi dialysis.

Beberapa studi observasional menunjuk kan rendahnya $25(\mathrm{OH})$ D dan 1,25 $(\mathrm{OH}) 2 \mathrm{D}$ pada pasien Chronic Kidney Disease dan Endstate Renal Disease termasuk hilangnya protein yang mengikat vitamin D dalam urin, sintesis tidak efektif setelah terpapar radiasi ultraviolet dan berkurangnya asupan gizi (Wolf et al, 2007; Bhan ,2010).

Rendahnya kadar D $25(\mathrm{OH})$ pada pasien dengan Chronic Kidney Disease dan Endstate Renal Disease telah dikaitkan dengan resiko yang lebih tinggi dari seluruh penyebab kematian pada penyakit ginjal. Dalam Journal Clinical of American Society of Nephrology tahun 2009 menyebutkan bahwa pemberian paricalcitol dapat menurunkan kadar Hormon Paratiroid, sedangkan ergocalciferol tidak menurunkan kadar Hormon Paratiroid. Pada penelitian secara meta-analisis menunjukkan bahwa terapi vitamin D aktif telah terbukti menurunkan kadar Hormon Paratiroid (Kovesdy et al, 2012).

Secara keseluruhan manfaat hasil penelitian ini adalah pemberian 1,25 dihydroxyvitamin $\mathrm{D}$ (calcitriol $0,5 \mu \mathrm{g} /$ hari) pada pasien penyakit ginjal kronikstadium Vyangmenjalanihemodialisis, dapat menurunkan resiko komplikasi atherosklerosis melalui penurunan kadar Fibroblast Growth Factor-23 dan penurunan albuminuria. Dari hasil penelitian ini menunjukkan dapat digunakannya 1,25 dihydroxyvitamin D (calcitriol) sebagai terapi alternatif atau suplementasi dalam penatalak sanaan pasien penyakit ginjal kronik stadium $\mathrm{V}$ yang menjalani hemodialisis.

Pada penelitian ini masih terdapat eterbatasan yaitu:

a. Penelitian ini hanya melibatkan satu center dengan subyek penelitian dan jangka waktu penelitian yang terbatas.

b. Penggunaan obat rutin yang berbeda-beda pada masing-masing subyek penelitian tidak dapat diseragamkan sehingga tidak diketahui apakah terdapat pengaruh antara 
obat yang dikonsumsi pasien terhadap penyerapan vitamin D, kadar Fibroblast Growth Factor-23 dan albuminuria.

c. Penelitian ini memerlukan gradasi dosis vitamin $\mathrm{D}$, dalam hal ini dosis calcitriol, dimana perlu disesuaikan dengan level kadar 1,25 Dihydroxyvitamin D pada masing-masing individu, apakah dia masuk dalam kelompok defisiensi vitamin D (kadar serum vitamin $\mathrm{D}<20 \mathrm{ng} / \mathrm{ml}$ ) atau masuk dalam kelompok insuffisiensi vitamin $D$ (kadar serum vitamin $\mathrm{D}<30 \mathrm{ng} / \mathrm{ml}$ ), untuk mendapatkan dosis yang paling tepat.

\section{SIMPULAN}

Berdasarkan hasilpenelitian yang dilakukan, maka dapat diambil kesimpulan sebagai berikut :

1. Pemberian 1,25 dihydroxyvitamin D (calcitriol) dapat menurunkan kadar Fibroblast Growth Factor-23 pada pasien Penyakit Ginjal Kronik stadium V yang menjalani hemodialisis secara bermakna.

2. Pemberian 1,25 dihydroxyvitamin D (calcitriol) dapat menurunkan Albuminuria pada pasien Penyakit Ginjal Kronik stadium $\mathrm{V}$ yang menjalani hemodialisis secara bermakna.

\section{DAFTAR PUSTAKA}

Amico G dan Bazzi C. 2003. Pathophysiology of Proteinuria. Kidney Intl. 63: 809-25

Araya K, Fukumoto S, Backenroth R. 2005. A Novel Mutation in Fibroblast Growth Factor 23 Gene as a Cause of Tumoral Calcinosis. J Clin Endocrinol Metab. 90 (10): 5523-527.

Bhan I, Burnett BSA, Ye J, Tonelli M, Thadhani R. 2010. Clinical Measures Identify Vitamin D Deficiency in Dialysis. Clin J Am Soc Nephrol.5: 460-67.

Brantsma AH, Bakker SJL, De Zeeuw. 2006. Urinary Albumin Excretion as a Predictor of the Development of Hypertension in The General Population. J Am Soc Nephrol. 17: 331-35.

Cachofeiro V, Goicochea M, Garcia de VS, Oubina P, Lahera V, Luno J, et al. 2008. Oxidative Stress and Inflamation, a Link Between Chronic Kidney Disease and Cardiovascular Disease. Kidney Int. 74: 54-59.

Collins AJ. 2003. Cardiovascular Mortality in End Stage Renal Disease. Am J Med Sci. 325: 163-67.

De Groot T. 2009. Parathyroid Hormone Activates TRPV5 via PKA Dependent Phosphorylation. $J$ Am Soc Nephrol.20: 1693-704.

Farrow EG, Davis SI, Summers LJ. 2009. Initial FGF23Mediated Signaling Occurs in the Distal Convoluted Tubule. J Am Soc Nephrol. 20(5):955-60.

Gansevort. 2009. Healthy People With High Urinary Protein Levels Have Elevated Kidney Disease Risk. Available from URL: http://www.sciencedaily.com/.

Gibbons GH. 1997. Vasculoprotective and Cardioprotective Mechanism of Angiotensin-Converting Enzyme Inhibition the Homeostatic Balance Between Angiotensin II and Nitric Oxide. Clin Cardiol. 20: 18-25.

Goetz R, Beenken A, Ibrahimi OA. 2007. Molecular Insights Into the Klotho Dependent, Endocrine Mode of Action of Fibroblast Growth Factor 19 Subfamily Members. Mol Cell Biol. 27: 3417-28.

Inaba M, Okuno S, Imanishi Y et al. 2006. Role of Fibroblast Growth Factor-23 in Peripheral Vascular Nalcification in Non Diabetic and Diabetic Hemodialysis Patients. Osteoporos. 17: 1506-13.

Kendrick J dan Chonchol MB. 2008. Non Traditional Risk Factor for Cardiovascular Disease in Patients With Chronic Kidney Disease.Nat Clin Pract Nephrol. 4: 672-81.

Kovesdy CP, Lu JL, Malakauskas SM, Andress DL, Kalantar ZK, Ahmadzadeh S. 2012. Paricalcitol Versus Ergocalciferol For Secondary Hyperpara thyroidism in CKD Stages 3 and 4: A Randomized Controlled Trial. Am J Kidney Dis. 59(1): 58-66.

Kurosu H, Ogawa Y, Miyoshi M. 2006. Regulation of Fibroblast Growth Factor-23 Signaling by Klotho. J Biol Chem. 81: 6120-123. 
Lang CL, Wang MH, Chiang CK, Cheng Lu K. 2014. Vitamin D and The Immune System From Nephrologist's Viewpoint. ISRN Endocrinol: 2-10.

Liu S, Zhou J, Tang W. 2006. Pathogenic Role of Fgf23 in Hyp Mice. Am J Physiol Endocrinol Metab. 291: 38-49.

Llach F danYudd M. 1998. Pathogenic, Clinical and Therapeutic Aspects of Secondary Hyperparathyroidism in Chronic Renal Failure. Am J Kidney Dis. 32: 3-12

Montesa P, Rico G, Salguero S, Maicas T, Munoz T, Torino S, et al. 2009. Study ofoxidative stress in advanced kidney disease. Nefrologia. 29(5): 464-73.

Moscovici A dan Sprague SM. 2007. Role of Vitamin D Defficiency in Chronic Kidney Disease. J Bone Miner Res. 22: 91-94.

Newman D dan Price CP. 2001. Renal Function. In Tietz Fundamentals of Clinical Chemistry. Eds Burtis CA, Ashwood ER, $5^{\text {th }}$ Edition. WB. Saunders Company. USA: 698-722.

Payson O, McMenamin E, Lee L. 2004. Increased Prevalence of Oxidant Stress andInflammation in Patients with Moderate to Severe Chronic Kidney DiseaseKidney Int. 65: 1009-16.

Pedrinelli R, Glampletro O, Carmassi F, Melillo E. 1994. Microalbuminuria and Endothelial Dysfunction In Essential Hypertension. Lancet. 344: 14-18.

Purwanto B. 2012. Hipertensi. Hipertensi (Patogenesis, Kerusakan Target Organ dan Penatalaksanaan. Sebelas Maret University Press: 3-58.

Rayner HC, Pisoni RL, Bommer J, Canaud B, Hecking E, Locatelli F, et al. 2004. Mortality and Hospitalization in Hemodialysis Patient in Five European Countries. Results From the Dialysis Outcomes and Practice Pattern Study (DOPPS). Nephrol Dial Transplant. 19: 108-120

Sarnak MJ, Levey AS, Schoolwerth AC, Coresh J, Culleton B, Hamm L, et al. 2003. Kidney Disease as aRisk Factor for Development of Cardiovascular Disease. Circulation. 108: 2154-69.

Shimada T, Hasegawa H, Yamazaki Y. 2004. FGF-23 is a Potent Regulator of Vitamin D Metabolism and Phosphate Homeostasis. J Bone Miner Res. 19(3): 429-35.

Shimada T, Mizutani S, Muto. 2001. Cloning and Characterization of FGF23 as a Causative Factor of Tumor-Induced Osteomalacia. Proc Natl Acad Sci. 98: 6500-505.

Suhardjono. 2009. Kelainan Kardiovaskular Pada Penyakit Ginjal Kronik. Penatalaksanaan Penyakit Ginjal Kronik dan Hipertensi. Jakarta, Pernefri: 36.

Teng M, Wolf M, Lowrie E, Ofshun N, Lazarus JM, Tadhani R, et al. 2003. Survival of Patients Undergoing Hemodialysis With Pericalcitriol and Calcitriol Therapy. N Eng J Med. 349: 44656.

Tentori F, Blayney M, Albert JM, Gillespi BW, Kerr PG, Bommer J, et al. 2008. Mortality Risk for Dialysis Patient With Different Levels of Serum Calcium, Phosphorus and PTH. Am J Kidney Dis. 52: 519-30.

Thomas R, Kanso A, Sedor JR. 2008. Chronic Kidney Disease and Its Complications. Prim Care Clin Office Pract. 35: 329-24.

Torres PU, Prie D, Molina Bletry V. 2007. Klotho: an Antiaging Protein Involved in Mineral and Vitamin D Metabolism. Kidney Int. 71: 730-37.

Urakawa I, Yamazaki Y, Shimada T. 2006. Klotho Converts Canonical FGF Receptor Into a Specific Receptor for FGF23. Nature. 444: 770-74.

White KE, Evans WE, O'Riordan JLH. 2000. Autosomal Dominant Hypophos phataemic Rickets is Associated with Mutations in FGF23. Nat Genet. 26(3): 345-48.

Wolf M, Shah A, Gutierrez O, Ankers E, Monroy M, Tamez H, et al. 2007. Vitamin D Levels and Early Mortality Among Incident Hemodialysis Patients. Kidney Int. 72: 1004-13. 
Yamashita T, Yoshioka M, Itoh N. 2000. Identification of a Novel Fibroblast Growth Factor, FGF23, Preferentially Expressed in the Ventrolateral Thalamic Nucleus of The Brain. Biochem Biophys Res Commun. 277: 494-98. 